\section{FROM DUPIN TO OEDIPA: THOMAS PYNCHON'S PARODIC TAKE ON DETECTIVE FICTION}

\section{Suradech Chotiudompant $^{1}$}

\begin{abstract}
This essay aims to investigate how Thomas Pynchon's The Crying of Lot 49, when juxtaposed with Edgar Allan Poe's Dupin short stories, can be read as a parodic reworking on the genre of detective fiction. By placing the works of the two authors in relation to theoretical lines of detective fiction, the essay intends to highlight how the world-views of the two authors are distinctively formed, especially in terms of a hermeneutical search for ultimate meaning.
\end{abstract}

\section{Theories of Detective Fiction}

Detective fiction makes use of conventional and normative structures in a rather obvious and conscious manner and, with its fairly patent formulae (see also Cawelti, 1976), its form can be easily distinguished. However, it is difficult to define detective fiction and one can only provide a rough, if not reductive, definition if one wishes it to be broad enough to cover its wide-ranging and nuanced spectrum. Yet a skeletal framework is needed to pave the way for our further analysis. It can be said that detective fiction centres round a mystery from which a detective, be he or she ama-

1 Instructor, Department of Comparative Literature, Faculty of Arts, Chulalongkorn University, Bangkok teur or professional, functions as a seeker of truth, of the disentanglement of the mystery. The denouement generally involves rational explanations, either with the revelation or exposure of the criminal or an alleviating explication which eases tensions gradually generated through the narrative. $^{2}$

Various writers have attempted to define this popular genre (see also Haycraft, 1946; Nevins, 1970; Knight, 1980; Most and Stowe, 1983). Yet most definitions can only be applicable to certain strands of detective fiction, since it has undergone a variety of structural and thematic evolutions and any attempt to define it by a fixed template inevitably risks the danger of simplification. Yu. K. Scheglov (1975:56) attempts to analyse detective fiction from a narratological perspective, dividing the narrative into two sub-stories, one inside the other. The inner story, the story of a crime, is placed inside the basic story, which provides the reader with a narrative frame. The Ground rules of detective fiction can mostly be identified in the basic story and this prompts the reader to respond to the text in a specific way. According to Scheglov (1975:66), the basic story consists of two main elements: the generic indicators of detective fiction and the particular world-view. The indicators of detective fiction include:

\footnotetext{
${ }^{2}$ This type of ending, which entails rational explanations of the seemingly inscrutable mystery can also be seen in the light of the fantastic paradigm of Tzvetan Todorov. The detective story, according to Todorov (1975:49-51), falls into the category of the uncanny since the mystery is explained rationally at the end, while in the narrative of the pure fantastic, such as Henry James's The Turn of the Screw, the mystery remains unresolved at the end.
} 
a) a mystery; b) unsuccessful straightforward attempts to solve it; c) a solution reached from some unexpected angle [...]; d) a gradual growth of tension as the investigation progresses $[\ldots] .^{3}$

Like Scheglov, Tzvetan Todorov (1977:44-45) maintains that detective fiction consists of two stories. Yet instead of having one inside the other as Scheglov stipulates, he prefers to have them successive in time: the first, that of the crime, ends before the second, that of the investigation. Detective fiction also constitutes a formal paradox, in which the first story is significant yet always absent, while the second story, though insignificant, is yet present. The second story, the story of the investigation, is normally narrated by a friend of the detective and the course of the narrative is presented through the viewpoint of the narrator. Todorov interestingly links the idea of the two stories to the Russian formalist notion of 'story' (fabula) and 'plot' (sjuzet) respectively. The first story, that of the

\footnotetext{
${ }^{3}$ It should be noted here that the indicators of the detective story proposed by Scheglov are similar to those stipulated by Cawelti. For Cawelti (1976:132), the conditions of the detective genre include: '(1) there must be a mystery, i.e. certain basic past facts about the situation and/or a number of the central characters must be concealed from the reader and from the protagonist until the end, or, as in the case of the inverted procedural story the reader must understand that such facts have been concealed from the protagonist; (2) the story must be structured around an inquiry into these concealed facts with the inquirer as protagonist and his investigation as the central action; however, the concealed facts must not be about the protagonist himself; (3) the concealed facts must be made known to the end.'
}

crime, which tells 'what really happened', is equated with 'story', the crude account waiting to be narrated, while the second story, that of the investigation, which explains 'how the reader (or the narrator) has come to know about it', is likened to 'plot', the already narrated story, filtered through such literary devices as point of view, characterisation and other narrative techniques.

There is also another significant difference between Scheglov's and Todorov's theoretical constructions of the detective genre. Since Scheglov's theory is mainly based on the Sherlock Holmes stories, it can only be applied in those cases where the detective is detached from the crime and enjoys the privilege of immunity from his or her involvement with the mystery. Perceiving that his theory of the two sub-stories can fall into the same trap as Scheglov, towards the end of his study Todorov distinguishes between two main types of detective fiction: the whodunnit and the thriller. His theory of two consecutive narratives can only be applied to the former, since, in the whodunnit, the first story is more significant yet is suppressed and retold only through the point of view of the narrator in the second story. However, in the latter, the two stories are fused together as the reader is no longer told about a crime anterior to the moment of the narrative; on the contrary, the narrative of investigation coincides with that of the crime. 'Curiosity', which for Todorov is a form of interest that proceeds from effect to cause and is dominant in the whodunnit, is substituted in the thriller by 'suspense', which is a form of interest that proceeds from cause to effect. In the thriller, the detective is also subject to a different form of fate: the detective loses the immunity he or she enjoys in the whodunnit. The reader is unlikely to imagine a detective in the 
whodunnit who get beaten up and constantly risks his or her life. However, in the thriller, this loss of immunity is ingrained in the characterisation of the detective.

Todorov's theory of detective fiction becomes more complicated when he introduces the third type: the suspense novel. This type of detective fiction combines the characteristics of the whodunnit and the thriller (Todorov, 1977:50):

It keeps the mystery of the whodunnit and also the two stories, that of the past and that of the present; but it refuses to reduce the second to a simple detection of the truth. [...] The two types of interest are thus united here - there is the curiosity to learn how past events are to be explained; and there is also the suspense: what will happen to the main characters? These characters enjoyed an immunity, it will be recalled, in the whodunnit; here they constantly risk their lives. Mystery has a function different from the one it had in the whodunnit: it is actually a point of departure, the main interest deriving from the second story, the one taking place in the present.

In Todorov's suspense novel, like his thriller, after the detective is integrated into the world of other characters, he or she is no longer analogous to the reader due to the loss of the privilege of observing from the outside. The detective in this kind of novel is so intertwined in the plot that the omission of his or her part in it will affect the progress of the narrative. The detective is therefore equated with other characters and may even be ac- cused of committing the crime. ${ }^{4}$ Unlike the detective in the whodunnit, whose exclusive task is to solve the crime, his counterpart in the suspense novel has more tasks, not only to disentangle the mystery, but also to escape risks he or she constantly encounters. Since in the who dunnit the detective assumes a more de tached role from the rest of the characters who are accused of the crime and who are potential criminals, this innocent character is basically equated with the reader, who in the same way independently observes the unfolding of the narrative. In the suspense novel, as in the thriller, however, the detective is involved in the crime as well as the investigation, thereby making the narrative more complex. In other words, there is no longer a locus where an independent observation is produced in this type of detective fiction.

Crime writers have also made various attempts to define detective fiction. For instance, in 1928 S. S. Van Dine laid down twenty rules that distinguish detective fiction, ${ }^{5}$ supporting the idea that detective

\footnotetext{
${ }^{4}$ Todorov (1977:51) calls this type of detective fiction 'the story of the suspect-as-detective' and considers it a sub-type of the suspense novel.

5 From the twenty rules Van Dine originally proposed, Todorov (1977:48-50) cites only his eight main rules: (1) the novel must have at most one detective and one criminal, and at least one victim (a corpse); (2) the culprit must not be a professional criminal, must not be the detective, must kill for personal reasons; (3) love has no place in detective fiction; (4) the culprit must have a certain importance: a) in life: not be a butler or a chambermaid, b) in the book: must be one of the main characters; (5) everything must be explained rationally; the fantastic not admitted; (6) there is no place for descriptions nor for psychological analysis; (7) with regard to information about the story, the following
} 
fiction to a certain degree follows a visible, though not always identical, pattern. Most of his rules deal with characterisation, stressing the importance of three main agents: a detective, a murderer, and at least one victim. The murderer then need not be a professional criminal and cannot be the same person as the detective. The reason is obvious: during the course of the narrative, the background of each character is gradually displayed and this exposition will eventually reveal the motive as to why the murderer has committed such a crime. Apart from the identity of the murderer, the motive of the crime also plays a central part in the fiction. It is, however, debatable how the rigorous norms set up by Van Dine can be of practical use when one applies them to detective fiction. For example, the notion of crime does not restrict itself solely to homicide, as Van Dine implies. In fact, certain mysteries in Sherlock Holmes stories sometimes involve petty thefts. In addition, figures such as chambermaids and butlers, which Van Dine deems too insignificant to be criminals, are hardly to be found in detective fiction nowadays. The list, in other words, needs a thorough updating.

Richard Knox also proposes his 'Ten Commandments', of which writers of the detective genre should be aware (see Ousby, 1997:67). Like Van Dine's twenty rules, Knox's guidelines also focus on the thematic angle, rather than formalist or structuralist ones proposed by Scheglov or Todorov. Some of Knox's rules are also dated: for example, the first rule maintains that the criminal must not be anyone whose

homology must be observed: 'author : reader = criminal : detective'; (8) banal situations and solutions must be avoided. For the complete list, see Haycraft, 1946:189-93. thoughts the reader has been allowed to follow. Agatha Christie challenges this rule in her The Murder of Roger Ackroyd, in which the narrator turns out to be the murderer himself. Knox also postulates that the detective himself must not commit the crime; however, this rule is violated by Alain Robbe-Grillet's Les Gommes, in which the detective knows he must be at a certain place and time to catch the criminal, but it transpires that when he turns up, he commits the murder himself.

The rules set forth by Van Dine and Knox are a clear example of how attempts to define detective fiction eventually undo themselves, in the same way that Scheglov's theory fails to accommodate the thriller and the hard-boiled novel. It is widely acknowledged that in writing and analysing detective stories, conventional rules are difficult to establish since, as in other literary genres, these rules are constantly challenged and renewed. Todorov (1977:43) is perhaps too hasty, arguing that 'detective fiction, the whodunnit in particular, is not the one which transgresses the rules of the genre, but the one which conforms to them'. Theoretical analyses proposed by these authors manifest the difficulties, if not the impossibilities, of the pursuits of fixed norms of detective fiction. The transition from the whodunnit to the thriller can be one example of how detective fiction changes through time and any analysis which attempts to find a fixed pattern of detective fiction may be doomed from the start.

\section{Edgar Allan Poe and the Tale of Ratiocination}

However dated they may seem, the rules proposed by Van Dine and Knox do raise one interesting issue. In their strain of detective fiction, the focal point is not the in- 
dividual psychology of each character but the interactive relationships among them that eventually form a narrative web. The reader is not given elaborate details of the development of each character, as the purpose of this kind of fiction is not as much insights into the human psyche as the pleasure derived from knowing who the murderer is and why he or she commits the crime. Characters in this type of detective fiction are similar to pieces in a chess game and their characteristics are not as important as their functions and positions. In other words, it becomes a game in which the writer, as represented by the criminal who creates a mystery, challenges the reader to find a solution. According to Ian Ousby (1997:67):

The detective story should not just be a puzzle. It should be a game - a 'great battle of wits between the writer and the reader' - pursued with rigour and frivolity in more or less equal parts. It needs rules, and above all it needed a spirit of fair play.

Their formulae for detective fiction, or what Cawelti (1976:99) terms 'the aestheticising of crime', were clearly influenced by imaginary tales written by Edgar Allan Poe ${ }^{6}$, who, for Jorge Luis Borges (1980:73), was the predecessor of detective

\footnotetext{
${ }^{6}$ For Cawelti, Poe is not as much a predecessor of the detective genre as an interesting transitional figure since his version of the detective story moves strongly towards the aestheticising of crime. The origin of the detective story proves to be complex and multiple; it needs to be considered alongside the myths that focus on crime, criminals, detectives, and the police, which then are synthesised with different archetypal patterns.
}

fiction. ${ }^{7}$ His imaginary personage, Charles Auguste Dupin, becomes the prototype for later detectives such as Hercule Poirot and Sherlock Holmes. ${ }^{8}$ What distinguishes Dupin from other detectives is that he is of a rather intellectual sort, picking up clues mostly by internalising the process and sorting the problem out in his head. The problem-solving process is, therefore, an internal one. Poe uses Dupin as an embodiment of analytic power, which, he believes, is different from ingenuity. The former requires a high level of intellectuality whereas the latter is, for Poe, nothing but a fanciful element. ${ }^{9}$ In this line of thought, Poe may have followed Samuel Taylor Col-

\footnotetext{
${ }^{7}$ However, for most critics, Poe is not the first inventor of detective fiction. He is considered to be one of the writers who popularised the genre. Knight (1998) traces the origin of detective fiction back to The Newgate Calendar, a collection of tales written in the late eighteenth century. However, Knight (2000:9) does maintain that with the figure of Dupin, the literary detective becomes a fully-formed character.

${ }^{8}$ Dupin appears in three of Poe's tales: 'The Murders in the Rue Morgue', 'The Mystery of Marie Roge_t', and 'The Purloined Letter'. Another tale, 'Thou Art the Man', is also considered by a number of critics to be a detective story (as it is included in Hoch, 1997).

${ }^{9}$ According to Poe (1986:191-92), 'the analytic power should not be confounded with simple ingenuity; for while the analyst is necessarily ingenious, the ingenious man is often remarkably incapable of analysis. [...] Between ingenuity and the analytic capability there exists a difference far greater, indeed, than that between the fancy and the imagination, but of a character very strictly analogous. It will be found, in fact, that the ingenious are always fanciful, and the truly imaginative never otherwise than analytic.'
} 
eridge's distinction between 'imagination' and 'fancy', proposed in his Biographia Literaria, first published in 1817, more than two decades before Poe published the first of his Dupin trilogy (see also Coleridge, 1975:167). Intellectuality, for Poe, is closely linked with Coleridge's imagination, since imagination, for both Romantic writers, constitutes a creative faculty, endowed by God, and its aim is to impose order and form upon raw materials perceived by the five senses. In the same manner, imagination is indispensable in art as it helps the author work on crude experience, enabling him or her to give it a proper order and form (see also Brett, 1969). This idea of intellectual imagination is appropriate when placed in our framework, as detective fiction, expected to be a well-wrought literary form as it were, needs meticulous planning and coherence.

For Poe, detective fiction, or what he himself prefers to call 'the tale of ratiocination', works backwards: the author knows the solution to the mystery from the start and tries to work his or her way back to the beginning. In 'The Philosophy of Composition', Poe (1986:480) maintains that for good artists the act of working backwards is compulsory:

[...] every plot, worth the name, must be elaborated to its dénouement before anything be attempted with the pen. It is only with the dénouement constantly in view that we can give a plot its indispensable air of consequence, or causation, by making the incidents, and especially the tone at all points, tend to the development of the intention.

What is interesting is that the arrangement of details, from the occurrence of the mystery to its disentanglement, needs to be cogent as well as self-consistent. It need not be exactly true to life, but true to the in- ternal structure to which it adheres. For Timothy Steele (1982:562), Poe does not work from experience to form; on the contrary, 'he conceives a pre-established design and then casts about for material to accommodate the design'. This 'preestablished design' is where the analytical faculty comes to be of use: the author needs to construct his or her narrative cogently and coherently since the reader, after being provided with ample clues, is encouraged, along with the detective, to unravel the mystery, chiefly by using the method of deduction. Even though the ending may not be in conformity with the reader's guess, it must be consistent with the whole course of the narrative. ${ }^{10}$ The craft of ratiocination can be explained in a historical manner. According to Stephen Knight (1980:42-43):

Poe combines the twin
nineteenth-century legends of the
scientist and the artist. [...] One of the
great excitements for the intelligentsia
of the period was the growing sense
that a sufficiently patient inquirer could
explain the structure of puzzling
phenomena. Another powerful theme,
found mostly in art, was that the fully
sensitive individual could pass through
the limits of the physical environment
to see and know at some higher level.

The combination of artistic and scientific discourses in Poe's detective narrative, therefore, reflects the faith in humanism; that is, the human capability to comprehend the complexity of natural or supernatural phenomena.

\footnotetext{
${ }^{10}$ David Van Leer (1983:75) links this notion of self-consistency in Poe's detective fiction with Poe's own theory of fiction. Poe's coherence model of truth, he argues, is in practice pertinent to his own principle of 'the unity of effect'.
} 
In addition, Poe is also pioneering in his introduction of the figure of the narrator who is not the detective. For Cawelti (1976:83$84)$, there are certain formal reasons that necessitate the intermediary figure of the narrator. With this character, writers can not only misdirect the reader's attention and prevent him or her from solving the crime prematurely, they can also make the moment of solution an extremely dramatic and surprising climax by keeping the reader away from the detective's point of view. The narrator, for Scheglov (1975:64), also represents the average reader and is depicted as relatively obtuse and mediocre. However, the narrator should not be analysed only in terms of structure, as the emergence of this mediatory figure also has sociological implications. For Knight (1980:43-44), it signals the simultaneous emergence of the individualising process whereby an individual could also respond to the material in his or her own way:

[that the narrator] provides a figure of identification for the audience is in itself an emblem of individualism. [...] Individualised and especially characterised narrators embody the concept that people know the world and exist in it as individuals, not as part of an integrated, mutually reliant society.

In other words, the emergence of the narrator, who is a friend of (and at the same time a foil to) the detective, coincides with the developing bourgeois consciousness, particularly of the avid magazine readers who followed a series of Poe's tales.

As we have seen, even though Poe wrote only a handful of detective tales, he set up a relatively new literary creation to offer contemporary readers. In fact, like other literary genres, detective fiction emerged at the same time as its readers, who responded to the fiction in a specific manner (see also Hernández Martín, 1995:3-11). Borges confirms this notion, claiming that in creating detective stories, Poe institutionalised the reader of detective fiction. The beginning of the essay, 'The Detective Story', sees Borges (1999:492) attempting to read Don Quijote in the manner of detective fiction:

'In a place in La Mancha whose name I do not wish to recall, there lived, not long ago, a gentleman ...' Already this reader is full of doubt, for the reader of detective novels reads with incredulity and suspicions, or rather with one particular suspicion.

For example, if he reads: 'In a place in La Mancha .., he naturally assumes that none of it really happened in $\mathrm{La}$ Mancha. Then: 'whose name I do not wish to recall' — and why didn't Cervantes want to remember? Undoubtedly because Cervantes was the murderer, the guilty party. Then: 'not long ago' - quite possibly the future holds even more terrifying things in store.

The reader of detective stories, as Borges implies, needs to possess a certain degree of suspension of belief in everything that is told to him or her and is supposed to select only relevant hints that can eventually lead to the criminal, who carries out a crime within the rational framework. This tendency towards self-critical reading is also supported by Jorge Hernández Martín (1995:11):

The detective story reader is a conscious reader who questions his or her own intuitions and provides tentative evidence for the feeling of 
suspicion on the way to a conclusion. In some rational manner, the reader must account for feelings and impressions in terms of facts and argument. The act makes a critic out of the reader for the purposes of fiction.

In this sense, the reader, therefore, is equated with a detective and both of them are similarly engaged in their search for rational explanations of the mystery. ${ }^{11}$ They need to use the basic method of reading and interpreting clues, or what Peter Hühn (1987:455) identifies as the 'hermeneutic circle', which 'involves devising interpretive patterns to integrate signs and then using new signs to modify and adjust these patterns accordingly'. To a degree, this reading process is analogous to the scientific method of deduction: Dupin prefers to deduce conclusions from his own closed system of generalised concepts to bolster his thinking process. The detective's closed system of deduction can be attributed to his own method of reasoning, which, for Van Leer (1993:70), 'depends on the logical inevitability of any thought process'. This unavoidably leads to a relatively simplified rendition of the real since the system of cause and effect is needed in the process of detection to explain the seemingly

${ }^{11}$ Van Dine also identifies this analogy in his list of twenty rules. However, it remains to be argued whether the reader identifies himself or herself more with the detective than with the narrator. Even though the reader is invited, in terms of formal structure, to identify with the figure of the narrator since the detective's feelings and preceptions remain largely hidden, the reader is at times discouraged from identifying with the narrator as the narrator represents a somewhat below average reader, as opposed to the detective who seems to be equipped with a god-like intelligence. In my opinion, the identification of the reader is no longer static and wavers between the narrator and the detective. inscrutable mystery. Once this causal law is applied, evil is reduced to a simple model of stimulus and response. Truth in Poe's narrative, therefore, assumes a distinctive air. According to Van Leer (1993:75): 'truth is true not because it corresponds to an external reality but simply because it is internally self-consistent and hangs together ('cohere')'.

Detective fiction, thanks to Poe, becomes an intellectual game between the author and the reader, where reason is a predominant element (see also Caillois, 1983). It becomes a stage where hints invariably lead back to the criminal and there are always rational relationships between hints and the eventual discovery of the criminal. The law of cause and effect is privileged in this type of fiction and the reader is invited to play along, using clues the detective gradually picks up from the crime scene, from interviews with involved parties, and from various other investigations. Reading Poe's fiction, the reader is exposed to an awareness of a certain form of attaining truth, a means of knowing the world. The points at stake in reading Poe's tales are not only who the criminal is, but also what 'truth' and 'world' are, how they may be reconstructed, and what follows from that construction.

\section{From Dupin to Oedipa}

First published in 1966, ${ }^{12}$ Pynchon's The Crying of Lot 49 can be seen to follow the pattern of detective fiction, especially in the sense that its female protagonist's encounters

\footnotetext{
${ }^{12}$ Part of the novella was originally published in Esquire in 1965 under the title 'The World (This One), the Flesh (Mrs Oedipa Maas), and the Testament of Pierce Inverarity'.
} 
with a mysterious underground post system represent a search for truth. The novella embodies an interesting development of the detective genre while conforming to the basic paradigm of mystery and an attempt by a protagonist to unravel it. The fact that the protagonist is named Oedipa is telling since, for some critics (see Hartman, 1975; Grossvogel, 1979), Sophocles's tragedy Oedipus Rex is hailed as a prototype of detective fiction, with its plot entailing the disentanglement of a mystery (Oedipus being in adamant search of his father's killer). In the same way, the origin of The Crying of Lot 49 involves the death of Pierce Inverarity, Oedipa's ex-lover. However, there remain certain differences between traditional detective stories and this novella: Oedipa is not intended to be a detective and need not scrutinise the reason for Pierce's death. Their remaining connection is that his will requests that she be an executor of his estate in San Narciso.

As she sets about exploring the property of the real-estate mogul, she is increasingly aware of the existence of an underground, somewhat anarchic organisation called the Tristero, in which Inverarity may have been involved. The symbol of the organisation is a muted posthorn, marking its status as an alternative, silenced channel of communication. She takes upon herself the responsibility to account for this secret organisation:

If it was really Pierce's attempt to leave an organised something behind after his own annihilation, then it was part of her duty, wasn't it, to bestow life on what had persisted, [...] to bring the estate into pulsing stelliferous Meaning, all in a soaring dome around her? (Pynchon, 1996:56)
Paradoxically, the more Oedipa discovers the traces and signs of the secret organisation, the more agitated she becomes, unsure of its existence. Unlike traditional detectives who become increasingly certain of the murderer upon gathering more clues, Oedipa is aware that the existence of the organisation may simply be conjured up by her own fantasy and hallucination:

Either Trystero ${ }^{13}$ did exist, in its own right, or it was being presumed, perhaps fantasied by Oedipa, so hung up on and interpenetrated with the dead man's estate (Pynchon, 1996:75).

In this sense, the analogy between her and Oedipus is clear, as Mendelson (1978:118) argues: both begin searching for the solutions to their mysteries as almost detached observers, only to discover how deeply implicated they are in what they find. Unlike Poe's Dupin, who enjoys immunity in his inquests, Oedipa is exposed to the uncertainty surrounding the emergence of an alternative system that can easily rob her of sanity. The Crying of Lot 49 thus gravitates towards what Todorov calls 'the suspense novel' since, as the narrative unfolds, Oedipa finds out that not only her own state of mind but also her companions' lives are constantly put at risk. ${ }^{14}$

\footnotetext{
${ }^{13}$ Pynchon makes it clear throughout the novella that Tristero can alternatively be spelt Trystero, signalling its relation to the word 'tryst'.

14 This is evidenced in the apparent suicide of the director Randolph Driblette, the disappearance of Metzger her co-executor, the arson at a used bookshop where she found Wharfinger's text, and the madness to which $\mathrm{Dr}$ Hilarius has succumbed.
} 
Furthermore, the name Oedipa is appropriate since what she is doing can be construed as a willingness to let herself be seduced by her 'father figure', Inverarity, to interpret the reality bestowed by him. ${ }^{15}$ The sense of truth and reality can be partially seen in his name as it indicates such words as 'verity' or 'veracity'. ${ }^{16}$ In this sense, the Tristero can be linked to Inverarity's 'estate' on a deeper level, not only in that Inverarity possesses stamps that are used in the Tristero system or that he might be directly involved in the organisation itself, but also because they make Oedipa (ironically given her search for truth) question what she means by truth and reality and wonder whether perhaps the Tristero is part of Inverarity's 'estate', awaiting her discovery, or is generated out of her fantasy and paranoia. It should be noted that Oedipa first becomes aware of the word Tristero when it is uttered in Richard Wharfinger's The Courier's Tragedy, a Jacobean play that she goes to see with Metzger. One of the acts ends as follows (Pynchon, 1996:50):

\footnotetext{
${ }^{15}$ Seduction occurs throughout the novella. On their first meeting, Metzger tries to seduce Oedipa by asking her to play 'Strip Botticelli' (Pynchon, 1996:23). The motel where Oedipa stays in San Narciso is called Echo Courts, pointing to the myth of Narcissus, whose appearance seduced the nymph Echo yet whose love she cannot win. The face of the nymph on a sign in front of the motel is much like Oedipa's and yet its mythical relationship is somewhat thwarted: "[The nymph on the sign] was smiling a lipsticked and public smile, not quite a hooker's but nowhere near that of any nymph pining away with love either' (Pynchon, 1996:16).

16 Tony Tanner (1982:57) suggests that 'the name itself can suggest either un-truth or in-the-truth; I have seen it glossed as 'pierces or peers into variety' and 'inverse' and 'rarity'.'
}

No hallowed skein of stars can war, I trow, Who's once been set his tryst with Trystero.

The reaction the word has on Oedipa is overwhelming: 'the word hung in the air as an act ended and all lights were for a moment cut; hung in the dark to puzzle Oedipa Maas, but not yet to exert the power over her it was to' (Pynchon, 1996:51).

Puzzled by the play, Oedipa makes her way backstage to ask the director, Randolph Driblette, what he knows of Inverarity or the secret organisation. Driblette, annoyed at her interest in the text, rather than in the performance as such, retorts:
'You don't understand', [Driblette is] getting mad. 'You guys, you're like Puritans are about the Bible. So hung up with words, words. You know where that play exists, not in that file cabinet, not in any paperback you're looking for, but' - a hand emerged from the veil of shower-steam to indicate his suspended head — 'in here. That's what I'm in for. To give the spirit flesh. The words, who cares? They're rote noises to hold line bashes with, to get past the bone barriers around a [sic] actor's memory, right? But the reality is in this head. Mine. I'm the projector at the planetarium, all the closed little universe visible in the circle of that stage is coming out of my mouth, eyes, sometimes other orifices also' (Pynchon, 1996:53-54).

His reply is worthy of being quoted in full since it elicits the dubeity and multiplicity that surround textual interpretation and a loss of original meaning or ultimate truth. For Driblette, there is no original or transcendental meaning but a variety of interpretations, dependent upon where they are created. It is the disappearance of centre 
and the substitution of self that are implied when Driblette says that he is 'the projector at the planetarium'. Oedipa's meeting with the director has significant implications as she starts to realise that perhaps the existence of the Tristero may arise out of her own construction of reality, of a paranoid belief that there must be an alternative reality underlying all these seemingly relevant traces. This leads her to write down a haunting question, 'Shall I project a world?', in her memo book, as if to remind herself that solipsism is somehow unavoidable. At stake are the related issues of reading and interpretation: how can Oedipa be sure that her understanding is justified and how much do paranoia and fantasy play a part in her attempt to make sense of the whole event? Following this line, Oedipa's reading can be related to Paul Ricoeur's concept of reading as propriation (Ricoeur, 1981:158):

[...] that the interpretation of a text culminates in the self-interpretation of a subject who thenceforth understands himself better, understands himself differently, or simply begins to understand himself.

For Ricoeur, meaning is no longer a stable entity awaiting the reader's discovery of the author's intention. Rather, it is a product of the interactive clashes between the text and the reader, of how readers reveal themselves in their attempts to appropriate the text. Truth and meaning thus change every time as the accumulative experience of the reader is always disparate. For Oedipa, truth has never before been considered so far-fetched; now that she learns that her own self plays an active part in constructing reality, she realises that ultimate truth may no longer be attainable.
To make matters more complicated, the issues of intention and chance are also brought to light, as Oedipa is never certain whether her experiences are actually preordained or whether they are simply contingent events. This can be seen in the scene in which, after she meets Metzger and he claims that he was once a child actor named Baby Igor, his past image appears on screen. The contingency of the whole scene amazes Oedipa and makes her wonder: 'Either he made up the whole thing, Oedipa thought suddenly, or he bribed the engineer over at the local station to run this, it's all part of a plot, an elaborate, seduction, plot' (Pynchon, 1996:19). Oedipa thus wonders whether the reality that presents itself to her may not be totally fortuitous, but may perhaps be manipulated by a mastermind. This is especially stressed towards the end of the novella when Mike Fallopian reminds Oedipa that perhaps the existence of the Tristero and its accompanying signs and traces may be part of a prank set up by Inverarity:

'But there's another angle too.' She sensed what he was going to say and began, reflexively, to grind together her back molars. A nervous habit she'd developed in the last few days. 'Has it ever occured to you, Oedipa, that somebody's putting you on? That this is all a hoax, maybe something Inverarity set up before he died ( Pynchon, 1996:115-16).

Oedipa somehow knows what Fallopian is going to say, as it is what she herself has thought for a long time but has kept at the back of her mind. If the whole thing becomes a set-up created particularly for her, it means that there is no such thing as ultimate meaning or truth (symbolised in the existence of the Tristero itself). Moreover, it signals that the truth about the 
Tristero is more complicated, especially considering 'symmetrical four' (Pynchon, 1996:118) explanations available to account for Oedipa's discovery:

Either you have stumbled indeed, without the aid of LSD or other indole alkaloids, on to a secret richness and concealed density of dream; on to a network by which $\mathrm{X}$ number of Americans are truly communicating whilst reserving their lies [...]. Or you are hallucinating it. Or a plot has been mounted against you, so expensive and elaborate [...]. Or you are fantasying some such plot, in which case you are a nut, Oedipa, out of your skull (Pynchon, 1996:117-18).

For Oedipa, these four equally plausible explanations of the whole phenomenon point to the fact that reality and truth can be constructed, influenced, and even manipulated by her own self, by her delusion and paranoia, by other people who have vested interests, or simply by chance. This realisation of the flimsy nature of reality makes Oedipa aware of the void beneath the web of events that make up her reality:

That night she sat for hours, too numb even to drink, teaching herself to breathe in a vacuum. For this, oh God, was the void. There was nobody who could help her. Nobody in the world. They were all on something, mad, possible enemies, dead (Pynchon, 1996:118).

This sophisticated view of reality is also highlighted in the novella's conclusion when Oedipa appears at an auction upon hearing that a Tristero representative may turn up to buy the stamps. The narrative comes to a close just as the auction is about to begin, leaving the reader in suspense: 'the auctioneer cleared his throat. Oedipa settled back, to await the crying of lot 49' (Pynchon, 1996:127). Pynchon thus does not explain which of the symmetrical four explanations is right. As with the case of Henry James's The Turn of the Screw, ${ }^{17}$ the ending is not so much an opening of possibilities of various endings as a confirmation that perhaps the reader will never know what the ending is, in the same way that they will never know what truth and reality are. $^{18}$

According to Mendelson (1978:135), the number 49 of the novella's title has a religious subtext, especially if one views the ending as a parody of Pentecost:

Because Pentecost is the Sunday seven weeks after Easter - forty-nine days. But the word Pentecost derives from the Greek for 'fiftieth'. The crying — the auctioneer's calling of the forty-ninth lot is the moment before a Pentecost revelation, the end of the period in which the miracle is in a state of potential, not yet manifest.

Number 49 thus signals an approximation to the moment of revelation; yet this critical moment seems to be frozen in time as the revelation never seems to arrive. ${ }^{19}$ This is in

${ }^{17}$ The manager of Echo Courts is called Miles, the same name as that of the boy protagonist in The Turn of the Screw.

${ }^{18}$ In Frank Kermode's words (1978:166), 'that plot is pointed to as the object of some possible annunciation; but the power is in the pointing, not in any guarantee'.

${ }^{19}$ For Tanner (1982:63-64), this is the reason why Pynchon chooses to use the word 'crying' rather than 'cry' in the novella's title: 'Oedipa is doomed to be the recipient/percipient of an ever-increasing number of clues which point to 
line with Oedipa's gradual recognition that perhaps ultimate truth may never be reached. Reality, for Pynchon, is thus a complex concept that cannot be taken for granted. Unlike Poe, Pynchon does not guarantee that an accumulation of hints will lead automatically to the unfolding of a mystery; in contrast, clues here lead to nothing but further mystification, confusing Oedipa and the reader alike. According to Mendelson (1978:123):

Pynchon's novel uses mechanisms borrowed from the detective story to produce results precisely the opposite of those in the model. Where the object of a detective story is to reduce a complex and disordered situation to simplicity and clarity, and in doing so to isolate in a named locus the disruptive element in the story's world, The Crying of Lot 49 starts with a relatively simple situation, and then lets it get out of the heroine's control: the simple becomes complex, responsibility becomes not isolated but universal, the guilty locus turns out to be everywhere, and individual clues are unimportant because neither clues nor deduction can lead to the solution.

While the ending of Poe's detective stories always promise the revelation of a murderer, that of The Crying of Lot 49 promises no such thing and leaves the reader in limbo. If the reality of Poe's world is clearly substantiated by the laws of cause and effect, Pynchon's version of reality does nothing but undermine these laws by showing how we mediate and manipulate our own realities.

other possible clues which point to other possible clues which ... there is no end to it. The 'cry' that might have ended the night is replaced by a 'crying' that can only extend it.'
Pynchon's novella serves as a parodic reflection of the tradition of detective fiction as a whole. Etymologically, the word 'parody' has its root in the Greek noun 'parodia', meaning 'counter-song' (see also Hutcheon, 1985:32). Yet, when looked at closely, the meaning of the term is ambiguous, since the prefix 'para' can mean 'counter' and 'against' as well as 'beside'. Linda Hutcheon (1985:6), taking this direction, posits that parody conveys a sense of repetition with difference and defines parody as:

a form of imitation, but imitation characterised by ironic inversion, not always at the expense of the parodied text. [...] Parody is, in another formulation, repetition with critical distance, which marks difference rather than similarity.

Parody then implies both sameness and difference at the same time, with the emphasis on the latter. In the same manner, Pynchon partially imitates generic conventions of detective fiction such as the introduction of mystery and a series of inquests conducted by an inquisitive protagonist. Yet the ending of Pynchon's novella is far from traditional as the detective (and, by proxy, the reader) is left suspended in a frozen moment awaiting revelation.

In twisting the ending and circumventing our expectations, Pynchon imparts an ideological deconstruction of traditional detective fiction. In general, the detective genre is regarded as a triumph of reason over chaos, a long-brewed product of the Enlightenment. From Poe to Conan Doyle, the detective had been provided with a god-like intelligence and legendary analytical powers that almost always 
helped him or her to find a solution to every mystery. For José Fernández Vega (1996:50-51, my translation), the detection is in a sense a way to explore the world with the privileged use of reasoning:

Detection is an aesthetic act of discovery by means of reasoning. The world, which lacks other meaning, provides an occasion to exercise the intellect and to test the reasoning that is used to find out causal chains: an aesthetic allegory of rationalist philosophy. [...] The detective is only an instrument of unilateral reason and this explains why the detective is a character which lacks human density but shows a great capability for travesty.

For Cawelti (1976:97), this is clearly shown in the ways detective writers choose to present the settings:

[...] the contrast between the locked room or the lonely country house and the outside world constitutes a symbolic representation of the relation between order and chaos, between surface rationality and hidden depths of guilt. [...] By solving the secret of the locked room, the detective brings the threatening external world under control so that he and his assistant can return to the peaceful serenity of his library, or can restore the pleasant social order of the country house.

Thus, traditional detective fiction (i.e. Poe's) is a representation of the triumph of order over chaos, of a return to the prevailing social status quo after a brief period of confusion and muddle.

As a form of parody, The Crying of Lot 49 attempts to demonstrate that this is not always the case. In reality, reason may not operate effectively in every case, either because reality may be solipsistically conceptualised or the causal chains may be manipulated and influenced. At any rate, human reason is shown to be defective in its claim to interpret natural phenomena; in addition, its limits are also highlighted, especially because reason, in fact, is nothing but a product of human projection, a wish to impose order upon the world of chaos. Pynchon's novella may be qualified as what Cawelti (1976:137) terms an 'antidetective' story, since it is a demonstration that order can no longer prevail over chaos, as Michael Holquist (1971:155) also argues:

instead of familiarity, it gives strangeness, a strangeness which more often than not is the result of jumbling the well known patterns of classical detective stories. Instead of reassuring, they disturb. They are not an escape, but an attack.

In other words, The Crying of Lot 49 exposes the reader to the fact that there are no longer causal chains that incorporate ultimate meaning. Perhaps behind these facades of realities already interpreted and mediated by human beings lies nothingness, the nada (the Spanish word for nothing) that Oedipa's husband is terrified of, hence the organisation name Tristero, signalling tristesse, a lingering sadness upon recognising that there is no transcendental meaning or ultimate truth to hold on to.

In essence, The Crying of Lot 49 can be construed as a testament of how the detective genre has so far progressed and of how its progress in terms of structure and theme has philosophical implications. Unlike Poe's, Pynchon's weltanschauung signals that the belief in the 'Word' has al- 
ready receded; in its place are 'clues' that Oedipa uncovers and utilises to create her version of meaningful truth, no longer 'Truth' but at least a truth that is justified by her own circumstances. ${ }^{20}$ In this sense, The Crying of Lot 49 can be regarded as a parody of the detective genre, especially in its claim to the truth, to the objective and explanatory powers of reason, and to the faithful obligation to overlook the essential void that lies underneath.

\section{References}

Auden, W. H. 1963. The Guilty Vicarage. In his The Dyer's Hand, pp. 146-58. London: Faber and Faber.

Bennett, Maurice J. 1983. The Detective Fiction of Poe and Borges. Comparative Literature 35.3:262-75.

Borges, Jorge Luis. 1980. El cuento policial. In his Borges oral, pp. 7088. Barcelona: Bruguera.

Borges, Jorge Luis. 1999. The Detective Story. Trans. by Esther Allen. In his The Total Library: Non-Fiction 19221986, ed. by Eliot Weinberger, pp. 491-99. London: Allen Lane.

Brett, R. L. 1969. Fancy and Imagination. London: Methuen.

Caillois, Roger. 1983. The Detective Novel as Game. Trans. by William W. Stowe. In The Poetics of Murder:

${ }^{20}$ It should also be observed here that The Crying of Lot 49 was published the same year that Jacques Derrida delivered the seminal essay 'Structure, Sign, and Play in the Discourse of the Human Sciences' at the Johns Hopkins University, challenging the totalising concepts of centre and intention.
Detective Fiction and Literary Theory, ed. by Glenn W. Most and William W. Stowe, pp. 1-12. San Diego: Harcourt Brace Jovanovich.

Castillo, Debra A. 1991. Borges and Pynchon: The Tenuous Symmetries of Art. In New Essays on The Crying of Lot 49, ed. by Patrick O'Donnell, pp. 21-46. Cambridge: Cambridge University Press.

Cawelti, John G. 1976. Adventure, Mystery, and Romance: Formula Stories as Art and Popular Culture. Chicago: University of Chicago Press.

Coleridge, Samuel Taylor. 1975. Biographia Literaria, ed. by George Watson. London: Dent.

Derrida, Jacques. 1978. Structure, Sign, and Play in the Discourse of the Human Sciences. In his Writing and Difference, trans. by Alan Bass, pp. 278-93. London: Routledge.

Duyfhuizen, Bernard. 1991. 'Hushing Sick Transmissions': Disrupting Story in The Crying of Lot 49. In New Essays on The Crying of Lot 49, ed. by Patrick O'Donnell, pp. 79-95. Cambridge: Cambridge University Press.

Fernández Vega, José. 1996. Una campaña estética. Borges y la narrative policial. Variaciones Borges 1:27-66.

Grossvogel, David I. 1979. Mystery and its Fictions: From Oedipus to Agatha Christie. Baltimore: The Johns Hopkins University Press. 
Hartman, Geoffrey. 1975. Literature High and Low: The Case of the Mystery Story. In his The Fate of Reading and Other Essays, pp. 203-22. Chicago: Chicago University Press.

Hassan, Ihab. 1987. The Postmodern Turn: Essays in Postmodern Theory and Culture. Columbus: Ohio State University Press.

Haycraft, Howard. (ed.). 1946. The Art of the Mystery Story. New York: Simon and Schuster.

Hayles, N. Katherine. 1991. 'A Metaphor of God Knew How Many Parts': The Engine that Drives The Crying of Lot 49. In New Essays on The Crying of Lot 49, ed. by Patrick O'Donnell, pp. 97-125. Cambridge: Cambridge University Press.

Hernández Martín, Jorge. 1995. Readers and Labyrinths: Detective Fiction in Borges, Bustos Domecq, and Eco. New York and London: Garland.

Hoch, Edward D. (ed.). 1997. Twelve American Detective Stories. Oxford: Oxford University Press.

Holquist, Michael. 1971. Whodunit and Other Questions: Metaphysical Detective Stories in Post-War Fiction. New Literary History 3:135-56.

Hühn, Peter. 1987. The Detective as Reader: Reading Concepts in Detective Fiction. Modern Fiction Studies 33.3:451-66.

Hutcheon, Linda. 1985. A Theory of Parody: The Teachings of Twentieth-Century Art Forms. London and New York: Methuen.
Hutcheon, Linda. 1988. A Poetics of Postmodernism: History, Theory, Fiction. London and New York: Routledge.

Hutter, Albert D. 1975. Dreams, Transformations, and Literature: The Implications of Detective Fiction. Victorian Studies 19.2:181-209.

Irwin, John T. 1994. The Mystery to a Solution: Poe, Borges, and the Analytic Detective Story. Baltimore: The Johns Hopkins University Press.

Johnston, John. 1991. Toward the SchizoText: Paranoia as Semiotic Regime in The Crying of Lot 49. In New Essays on The Crying of Lot 49, ed. by Patrick O'Donnell, pp. 47-78. Cambridge: Cambridge University Press.

Kaemmel, Ernst. 1983. Literature under the Table: The Detective Novel and its Social Mission. Trans. by Glenn W. Most. In The Poetics of Murder: Detective Fiction and Literary Theory, ed. by Glenn W. Most and William W. Stowe, pp. 55-61. San Diego: Harcourt Brace Jovanovich.

Kermode, Frank. 1978. Decoding the Trystero. In Pynchon: A Collection of Critical Essays, ed. by Edward Mendelson, pp. 162-66. Englewood Cliffs: Prentice-Hall.

Knight, Stephen. 1980. Form and Ideology in Crime Fiction. Basingstoke: Macmillan.

Knight, Stephen. 1998. Enter the Detective: Early Patterns of Crime Fiction. In The Art of Murder: New Essays on 
Detective Fiction, ed. by H. Gustav Klaus and Stephen Knight, pp. 10-25. Tübingen: Stauffenburg.

Knight, Stephen. 2000. General Introduction. In Two Centuries of Detective Fiction: A New Comparative Approach, ed. by Maurizio Ascari, pp. 5-14. Bologna: University of Bologna.

Kolodny, Annette, and Daniel James Peters. 1973. Pynchon's The Crying of Lot 49: The Novel as Subversive Experience. Modern Fiction Studies 19:79-87.

Levine, George. 1976. Risking the Moment: Anarchy and Possibility in Pynchon's Fiction. In Mindful Pleasures: Essays on Thomas Pynchon, ed. by George Levine and David Leverenz, pp. 113-36. Boston: Little, Brown and Co.

McHale, Brian. 1987. Postmodernist Fiction. London and New York: Routledge.

Mangel, Anne. 1976. Maxwell's Demon, Entropy, Information: The Crying of Lot 49. In Mindful Pleasures: Essays on Thomas Pynchon, ed. by George Levine and David Leverenz, pp. 87100. Boston: Little, Brown and Co.

Mendelson, Edward. 1978. The Sacred, the Profane, and The Crying of Lot 49. In Pynchon: A Collection of Critical Essays, ed. by Edward Mendelson, pp. 112-46. Englewood Cliffs: Prentice-Hall.

Nevins, Francis M., Jr. (ed.). The Mystery Writer's Art. Bowling Green: Bowling Green University Popular Press.
Nohruberg, James. 1978. Pynchon's Paraclete. In Pynchon: A Collection of Critical Essays, ed. by Edward Mendelson, pp. 147-61. Englewood Cliffs: Prentice-Hall.

O'Donnell, Patrick. (ed.). 1991. New Essays on The Crying of Lot 49. Cambridge: Cambridge University Press.

Ousby, Ian. 1997. The Crime and Mystery Book: A Reader's Companion. Hong Kong: Thames and Hudson.

Palmer, Richard E. 1969. Hermeneutics. Evanston: Northwestern University Press.

Palmer, Richard E. 1977. Postmodernity and Hermeneutics. Boundary 2 5:36393.

Petillon, Pierre-Yves. 1991. A Re-Cognition of her Errand into the Wilderness. In New Essays on The Crying of Lot 49, ed. by Patrick O'Donnell, pp. 127-70. Cambridge: Cambridge University Press.

Poe, Edgar Allan. 1986. The Fall of the House of Usher and Other Writings, ed. by David Galloway. London: Penguin.

Pynchon, Thomas. 1996 [1966]. The Crying of Lot 49. London: Vintage.

Rasch, William. 1992. Injecting Noise into the System: Hermeneutics and the Necessity of Misunderstanding. SubStance 67:61-76.

Ricoeur, Paul. 1981. Hermeneutics and the Human Sciences: Essays on Language, Action, and Interpretation, ed. and trans. by John B. 
Thompson. Cambridge: Cambridge University Press.

Riffaterre, Michael. 1980. Interpretation and Undecidability. New Literary History 12:227-42.

Rose, Margaret A. 1979. Parody/ /Metafiction: An Analysis of Parody as a Critical Mirror to the Writing and Reception of Fiction. London: Croom Helm.

Sanders, Scott. 1976. Pynchon's Paranoid History. In Mindful Pleasures: Essays on Thomas Pynchon, ed. by George Levine and David Leverenz, pp. 139-59. Boston: Little, Brown and Co.

Scheglov, Yu. K. 1975. Towards a Description of Detective Story Structure. In Generating the Literary Text, ed. and trans. by L. M. O. Toole, pp. 51-77. n.p.:n.pub.

Spanos, William. 1972. The Detective and the Boundary: Some Notes on the Postmodern Literary Imagination. Boundary 2 2:147-68.

Steele, Timothy. 1982. The Structure of the Detective Story: Classical or Modern? Modern Fiction Studies 27.4:555-70.

Tanner, Tony. 1982. Thomas Pynchon. London: Methuen.

Todorov, Tzvetan. 1975. The Fantastic: A Structural Approach to a Literary Genre, trans. by Richard Howard. Ithaca: Cornell University Press.

Todorov, Tzvetan. 1977. The Typology of Detective Fiction. In his The Poetics of Prose, trans. by Richard Howard, pp. 42-52. Oxford: Basil Blackwell.

Trotter, David. 1991. Theory and Detective Fiction. Critical Quarterly 33.2:66-77.

Van Leer, David. 1993. Detecting Truth: The World of Dupin Tales. In New Essays on Poe's Major Tales, ed. by Kenneth Silverman, pp. 65-91. Cambridge: Cambridge University Press. 